\title{
Understanding differential patterns in coral reef recovery: chronic hydrodynamic disturbance as a limiting mechanism for coral colonization
}

\author{
T. Shay Viehman ${ }^{1,2, *}$, James L. Hench ${ }^{2}$, Sean P. Griffin ${ }^{3}$, Amit Malhotra ${ }^{1,4}$, \\ Katharine Egan ${ }^{1,4}$, Patrick N. Halpin ${ }^{5}$
}

${ }^{1}$ National Oceanic and Atmospheric Administration, National Ocean Service, National Centers for Coastal Ocean Science, 101 Pivers Island Road, Beaufort, North Carolina 28516, USA

${ }^{2}$ Marine Laboratory, Nicholas School of the Environment, Duke University, 135 Duke Marine Lab Road, Beaufort, North Carolina 28516, USA

${ }^{3}$ National Oceanic and Atmospheric Administration, National Marine Fisheries Service, Restoration Center, 260 Guard Road, Aguadilla, Puerto Rico 00605, USA

${ }^{4}$ JHT Inc., 2710 Discovery Drive \#600, Orlando, Florida 32826, USA

${ }^{5}$ Nicholas School of the Environment, Duke University, Durham, North Carolina 27708, USA

\begin{abstract}
Coral reefs are subject to numerous physical disturbances, and post-disturbance coral recovery potential depends on subsequent re-colonization of impacted habitat. We examined divergent recovery trajectories at 2 proximal reefs disturbed by ship groundings that resulted in clearly delineated areas of altered substrate. Post-disturbance measurements of coral recruitment, survival, and changes in community structure were made approximately annually from 2009-2013 in undisturbed reference areas as well as disturbed pavement and rubble areas. Despite similar initial physical disturbances, there were marked differences between sites, with higher coral recruitment and survival on disturbed pavement than rubble bottom, reference reef, or restoration structures. Subsequent episodic disturbances from rubble mobilization could be a mechanism driving the divergent recovery patterns. To estimate whether local hydrodynamic conditions were sufficient to mobilize rubble, we used a combination of long-term monitoring, hydrodynamic modeling, and rubble transport mechanics to hindcast the potential for substrate mobility. Long-term model simulations of hydrodynamic forcing at the study sites showed multiple events where bottom-orbital velocities exceeded thresholds required to mobilize rubble via sliding or overturning. Our analyses indicate that wave energy mobilizes rubble substrate multiple times annually and suggests a physical limitation on survival of coral recruits relative to those on pavement substrate. Continued mobilizations may establish a positive feedback loop in which continued rubble clast mobilizations cause additional mechanical erosion or breakage and a shift to smaller rubble sizes that would subsequently mobilize at a lower level of hydrodynamic forcing and thus become subject to more frequent and sustained disturbances. The combination of multiple hydrodynamic disturbances and unstable substrate limits coral recovery and thus contributes to prolonged habitat loss.
\end{abstract}

KEY WORDS: Coral recruitment - Coral reefs - Disturbance recovery - Rubble mobilization . Waves $\cdot$ Ship groundings $\cdot$ Puerto Rico 


\section{INTRODUCTION}

Habitat degradation is a major contributor to the decline of coral reefs worldwide (Hughes et al. 2003, Hoegh-Guldberg et al. 2007). Coral reef structural complexity can be degraded by both human activities and climate-related stressors. Anthropogenic disturbances that can obliterate reef structure are often related to proximal human uses and include ship groundings (Jaap 2000, Riegl 2001) and blast fishing (Edinger et al. 1998). Loss of reef structure can also be caused by climate change related ecological disturbances, such as widespread coral death from severe bleaching events (Sheppard et al. 2002, 2005, Graham et al. 2006). Future climate change scenarios (e.g. ocean acidification) have been projected to degenerate reefs into rubble banks (HoeghGuldberg et al. 2007). Acute, episodic disturbances such as wave forcing from tropical cyclones (Stoddart 1969, Woodley et al. 1981, Harmelin-Vivien 1994) and tsunamis (Scheffers et al. 2009) can reduce the structural complexity of large sections of reef into extensive rubble fields. Repeated or multiple disturbances can also compound effects and slow recovery (e.g. Rasser \& Riegl 2002, Wakeford et al. 2008). The physical legacy of disturbance (e.g. degradation of reef into loose rubble) may result in prolonged habitat loss if colonization of new reef-building scleractinian species is unsuccessful.

Scleractinian corals thrive under a range of hydrodynamic conditions, although success varies by species, morphology, and geography. As sessile filter feeders, flow conditions affect prey capture (Sebens \& Johnson 1991, Piniak 2002), photosynthesis and respiration (Dennison \& Barnes 1988), and removal of waste products (Mass et al. 2010). Flow variability can also mediate corallivory, increasing net growth of corals (Lenihan et al. 2015). Exceeding normal hydrodynamic conditions, water motion can act as a disturbance to benthic marine organisms such as corals (Dayton 1971, Denny 1995). Wave forcing can cause mechanical breakage of colonies or dislodgment from substrate (Woodley et al. 1981, Connell et al. 1997, Madin 2005), and can limit the spatial distributions of coral species on reefs (Storlazzi et al. 2005). Effects of large disturbances are well known to have long-lasting impacts on coral communities (Done 1992, Connell 1997, Connell et al. 1997). After a disturbance, successful recruitment and survival of scleractinian corals are key limitations to the potential for future coral community development (Lirman \& Miller 2003) and reef complexity (Steneck et al. 2009); as foundation species, scleractinian corals cre- ate habitat through development of biogenic skeletal structure (Dayton 1972, Ellison et al. 2005, Bertness et al. 2006). Many factors can limit the potential for successful coral recruitment (Ritson-Williams et al. 2009), particularly the availability of suitable settlement substrate (e.g. consolidated hard-bottom, Pearson 1981). Although it is known that intervals between extreme events regulate coral community trajectories and return or reset communities to alternate or early successional stages (Done 1999, Hughes \& Connell 1999), less is known about how interactions between chronic hydrodynamic stress and reef structure (or lack of structure) may constrain the potential of a disturbed reef to recover to a coraldominated state.

We used a comparative and mechanistic approach to examine coral colonization and recovery trajectories within areas of localized reef destruction after ship grounding impacts. Coral recruitment and survival were compared between pavement and rubble disturbance sites relative to artificial structures and reference areas for $6 \mathrm{yr}$. Differential recovery trajectories observed at these sites suggest that physical mechanisms may limit post-disturbance colonization and contribute to observed patterns of colonization success. To explore this, we hindcasted potential limitations on colonization due to the frequency and intensity of hydrodynamic forces, specifically, whether ocean surface wave forcing was sufficient to intermittently mobilize rubble exposed by the initial ship grounding. The specific questions addressed are: (1) After an initial physical disturbance, how does coral colonization differ between exposed substrate, exposed unstable substrate, artificial structures with coral transplants, and a reference reef? (2) How is colonization success limited by abiotic factors, including near-bottom wave-orbital velocity and rubble substrate mobilization? (3) What is the threshold bottom-orbital velocity required to mobilize rubble substrate, and how frequently are these hydrodynamic conditions exceeded in the study area? (4) How does the time scale between potential hydrodynamic disturbance events compare with that of coral colonization?

\section{MATERIALS AND METHODS}

\section{Study sites}

The study was conducted on the southern coastal shelf of Puerto Rico, south of Bahia de Tallaboa (Fig. 1A). The area is primarily exposed to easterly 
A Location

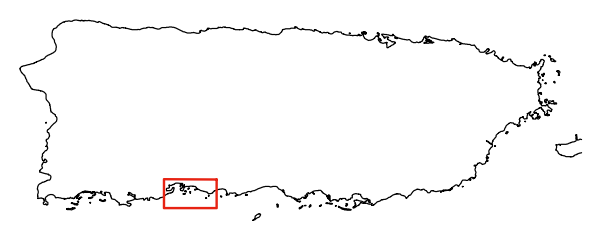

D Field sites and model domains

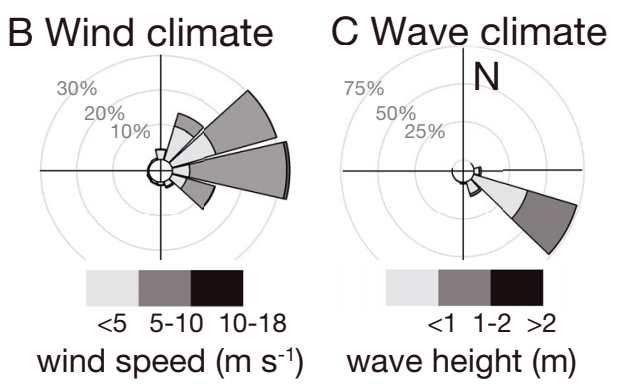

wind speed $\left(\mathrm{m} \mathrm{s}^{-1}\right)$ wave height $(\mathrm{m})$

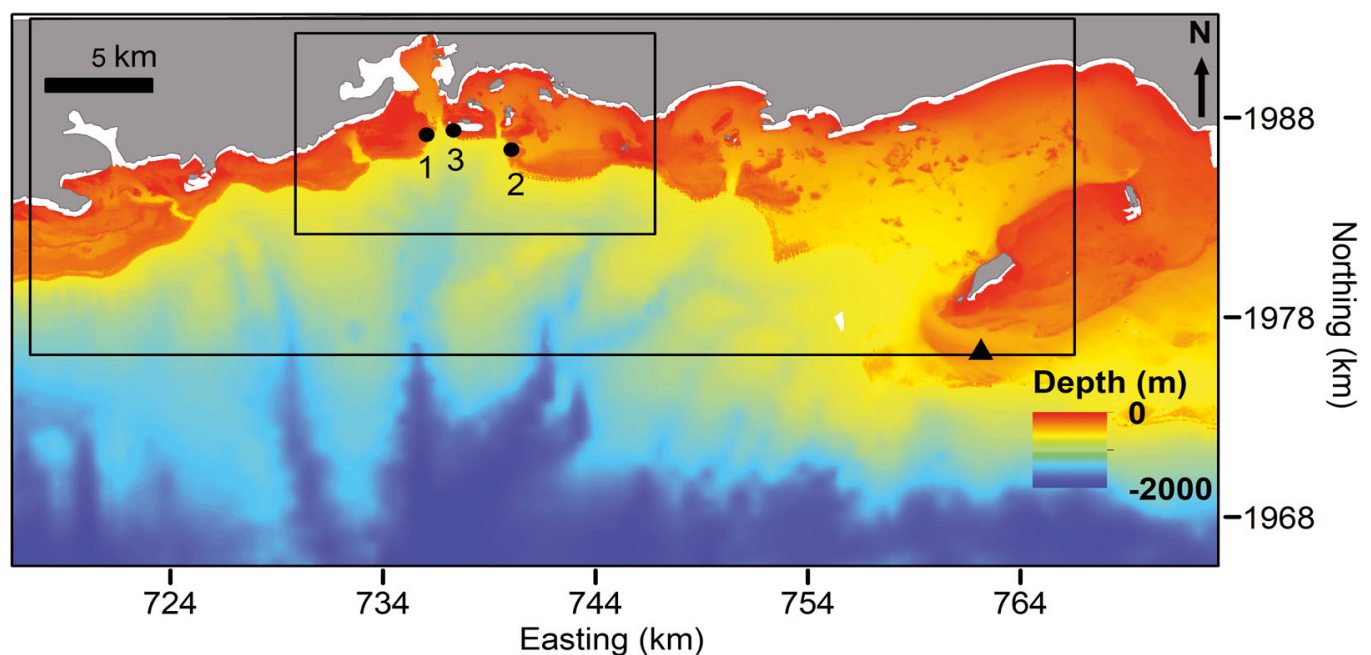

Fig. 1. (A) Study area on the south coast of Puerto Rico. (B) Climatological offshore wind and (C) wave height for Caribbean Coastal Ocean Observing System (CariCOOS) buoy data from 2010-2014. Histograms indicate directionality and frequency of occurrence. (D) Study area in Guayanilla and Tallaboa Bays with depths ranging from 0-2000 m. Black circles indicate locations of oceanographic instrument moorings: (1) pavement site, (2) rubble site, (3) central bay. Coral surveys were conducted at sites 1 and 2. Triangle indicates location of offshore CariCOOS buoy. Black rectangles indicate nested numerical model domains used for the wave hindcast simulations

trade winds and waves from the southeast (Fig. 1B,C). Water depths in the study area are 9-14 m but increase to more than $2000 \mathrm{~m}$ approximately $10 \mathrm{~km}$ offshore (Fig. 1D). Tanker vessels frequently transit the study area to access a liquefied natural gas terminal in Guayanilla Bay. Between November 2005 and April 2006, 2 vessels grounded on adjacent reefs, crushing and flattening the reef structural complexity within areas of impact. One vessel (TV 'Sperchios') disturbed approximately $1970 \mathrm{~m}^{2}$ of coral reef habitat into flattened pavement cleared of corals (hereafter termed 'pavement site'; Fig. 1). The second vessel (TV 'Margara') fractured approximately $6910 \mathrm{~m}^{2}$ of coral reef habitat, removing corals and the consolidated reef surface to expose geologic unconsolidated clastic rubble primarily composed of fossilized Acropora cervicornis (hereafter termed 'rubble site'; Fig. 1). Both grounding impact sites had similar depths (10-13 m). A reef site adjacent to the rubble site was used as a reference reef of unimpacted habitat. To test if coral recruitment oc- curred on available substrate in the geographic area of the study, restoration structures were included in the experimental design. Artificial structures were constructed and located within a subsection of the rubble area in 2006 to stabilize dislodged corals and partially replace structural complexity lost in the grounding impact. These structures (hereafter termed 'restoration structures') were constructed from dislodged pieces of reef limestone and concrete, with diameters ranging between 0.2 and $3.0 \mathrm{~m}$ and heights between 0.2 and $1.0 \mathrm{~m}$ (Fig. 1). Scleractinian corals and octocorals that survived the disturbance impact were transplanted onto restoration structures in 2006.

\section{Benthic surveys}

To evaluate changes in coral recovery after these 2 large and proximal disturbance events, we measured in situ coral recruitment annually at multiple levels of 

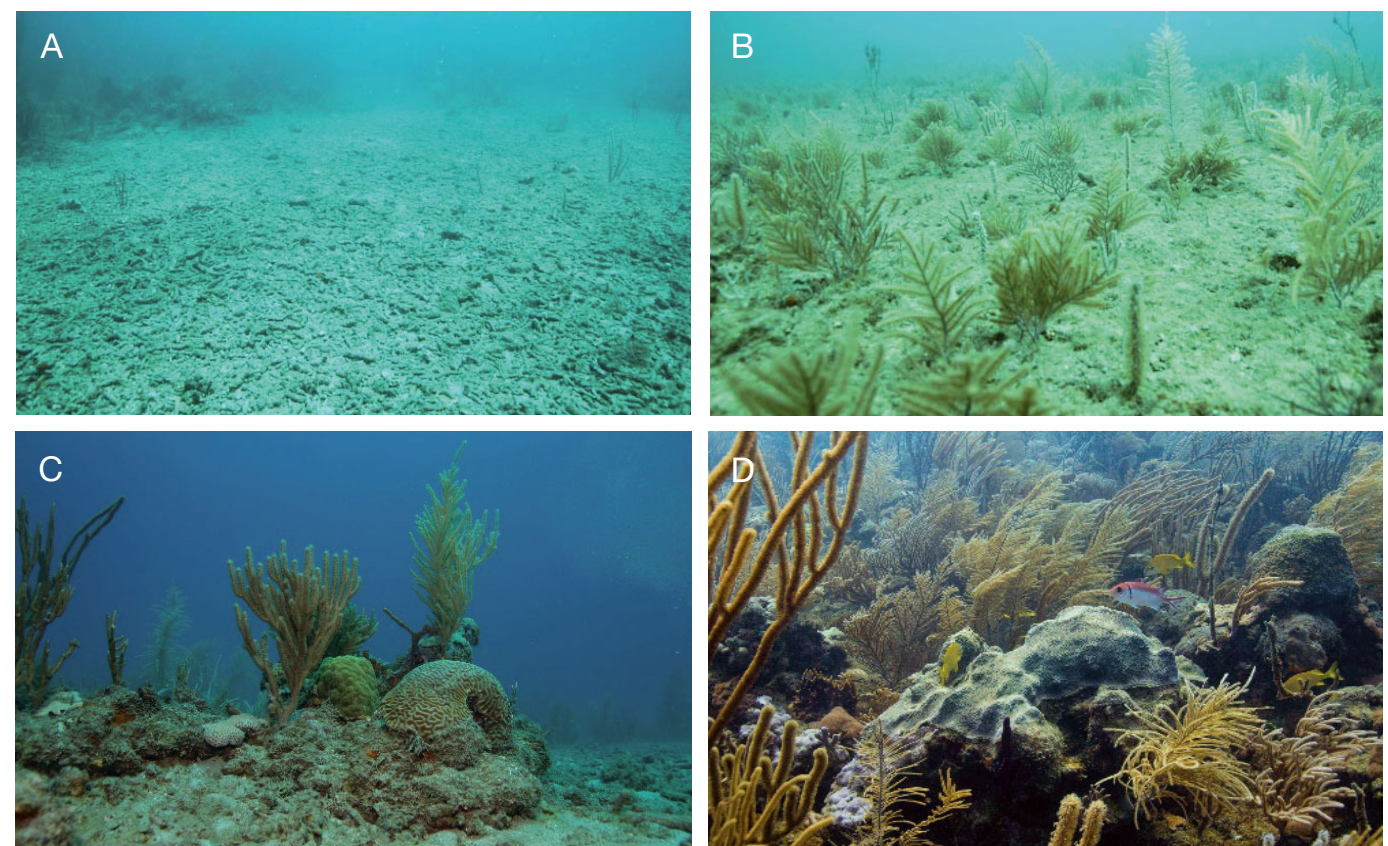

Fig. 2. Study locations including (A) rubble and (B) pavement areas injured by ship groundings, (C) artificial restoration structures, and (D) proximal reference site. In (A), the edge of the injury is visible at the top left

substrate stability and complexity. These levels were: (1) disturbed reef area at the rubble site; (2) disturbed reef area at the pavement site; (3) restoration structures within the rubble site; and (4) natural reef adjacent to the rubble site (Fig. 2). Within each level, permanent quadrats $(25 \mathrm{~cm} \times 25 \mathrm{~cm})$ were visually surveyed $(n=45$ in each of rubble disturbance and reference areas, and $n=30$ in each of pavement disturbance and restoration areas) approximately annually from 2008-2013. At each field sampling, new scleractinian and octocoral recruits $(\geq 0.5 \mathrm{~cm})$ within quadrats were visually identified by divers by species, size, and location within the permanent quadrat, and diagrammed onto quadrat maps for reference in future relocations. Existing (non-recruit) corals were identified within quadrats at each survey from 20092013. Scleractinian corals were identified to species, and octocorals were identified to genus. Survival of each individual was monitored in subsequent surveys by comparing mapped diagrams of new and existing corals. Survival at each site was calculated as the percentage of corals present at each time interval and present at the subsequent sampling. Photographs of benthic quadrats were collected at each survey and used for analyses of potential rubble movement (below) and change in benthic cover (for details see Section 1 in the Supplement at www.intres.com/articles/suppl/m605p135_supp.pdf). Change in cover for corals and octocorals (\%) between 2008 and 2013 was regressed against rubble cover (\%) to show the relationship of increases in coral and octocoral cover with rubble coverage at rubble, pavement, restoration, and reference sites.

Coral community composition and size distribution were surveyed visually with belt transects located adjacent to quadrats at rubble, reference, and pavement sites. Within the transect area $(10 \mathrm{~m} \times 1 \mathrm{~m})$, scleractinian corals were identified to species, and octocorals were identified to genus. Transect surveys in disturbed areas were conducted approximately annually from 2008 to 2013 (rubble disturbance; $\mathrm{n}=$ 8; pavement disturbance; $\mathrm{n}=4-6$ ) and in reference areas in 2008 (reference adjacent to rubble disturbance; $\mathrm{n}=10$ ) and 2011 (reference adjacent to pavement disturbance; $n=5$ ). No transects were surveyed on restoration structures due to the limited size of the structures. The change in octocoral and scleractinian coral density and richness between the first and last study years (2008 and 2013) was compared between the 2 disturbances using a Mann-Whitney $U$-test.

Rubble mobilization over time was investigated by comparing the change between survey events in rubble clast locations within individual quadrats. In each photograph of permanently located quadrats taken during benthic surveys, 3-5 individual rubble clasts with uniquely identifiable shapes were identified $(n=249)$ and then visually searched for in the same quadrat in subsequent years to test whether they could be located in approximately the same or different locations within the quadrat. 


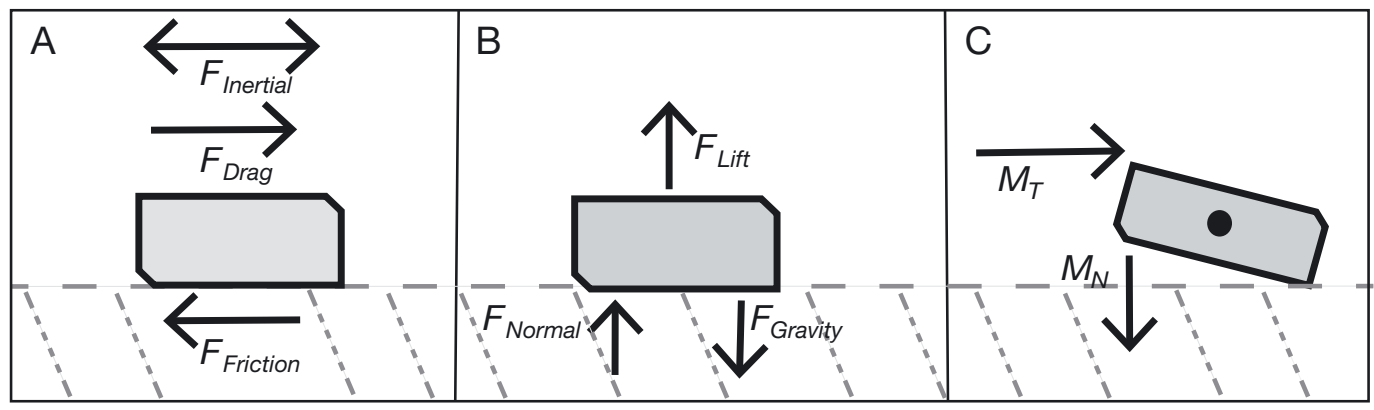

Fig. 3. Force diagrams for rubble mobility mechanics used to compute sliding stability thresholds from (A) horizontal and (B) vertical forces acting on rubble on a surface. Overturning stability thresholds were calculated using moments acting on rubble (C), where marks the axis of rotation for a rubble piece, $M_{T}$ is the sum of drag, inertia and lift force moments, and $M_{N}$ is the restoring gravitational moment

\section{Rubble transport model}

We modeled the potential mobility of unconsolidated rubble within the disturbed areas using a mechanistic approach to estimate hydrodynamic forces required to initiate rubble motion. This approach has been well developed in the literature to hindcast hydrodynamic forcing required to mobilize boulders during large wave events (Nandasena et al. 2011). Here, a clast is approximated by an idealized cuboid (defined by $a-, b$-, $c$-axes) that is acted upon by gravity $\left(F_{g}\right)$, normal $\left(F_{N}\right)$, lift $\left(F_{L}\right)$, friction $\left(F_{F}\right)$, drag $\left(F_{d}\right)$, and inertial $\left(F_{I}\right)$ forces (Fig. 3), where $F_{F}=\mu F_{N}$ and $\mu$ is the coefficient of static friction. Hydrodynamic forcing exceeding a critical threshold can initiate rubble clast motion by sliding or over-turning. Sliding occurs when (Fig. 3)

$$
F_{D}(t)+F_{I}(t)>\mu\left[F_{g}-F_{L}(t)\right]
$$

At the initiation of sliding, the forces on the left and righthand side of Eq. (1) are equal. Forces that are functions of water velocity $\left(F_{D}, F_{L}\right.$, and $\left.F_{I}\right)$ vary with time $(t)$ over a wave period $(T)$. The quadratic drag and lift forces due to waves are in phase with each other, but they are both $90^{\circ}$ out of phase with the inertial force. To estimate when rubble is mobilized, we evaluated when the total time-varying forces are maximum. Following Dean \& Dalrymple (1991), but extending their derivation to include the lift force, this occurs when

$$
F_{D, m}+\mu F_{L, m}+\frac{F_{I, m}^{2}}{4\left(F_{D, m}+\mu F_{L, m}\right)}-\mu F_{g}=0
$$

where the maximum drag force is $F_{D, m}=\frac{1}{2} \rho_{W} C_{D} A_{D} U_{m}^{2}$, the maximum lift force is $F_{L, m}=\frac{1}{2} \rho_{w} C_{L} A_{L} U_{m}^{2}$, and the maximum inertial force is $F_{I, m}=\rho_{W} C_{M} V\left(U_{I} \omega\right)$, where $\rho_{W}$ is the density of seawater $\left(1023 \mathrm{~kg} \mathrm{~m}^{-3}\right)$ and $\omega=$ $2 \pi / T$ is the wave frequency. The normal force $\left(F_{N}\right)$ can be expressed as $F_{g}=\Delta \rho V g$, where $\Delta \rho=\rho_{r}-\rho_{w}, \rho_{r}$ is rubble density, $g$ is acceleration due to gravity, and $V$ is the rubble volume. $C_{D}, C_{L}$, and $C_{M}$ are dimensionless coefficients of drag, lift, and added mass, respectively; $A_{D}$ is the cross-sectional area of a rubble clast perpendicular to the flow and $A_{L}$ is the area of a rubble clast parallel to the flow. The water velocity can be decomposed into contributions from currents and waves $\left(U_{m}=U_{c}+U_{w i}\right.$ e.g. Grant \& Madsen 1979). Substituting these expressions for forces and velocities into Eq. (2), and noting that the currents do not contribute to the inertial force, one can derive an expression for the threshold velocity at which rubble is mobilized via sliding (see Section 4 of the Supplement for full derivation and solution).

Now, from the free-body diagram, rubble overturning occurs when

$$
F_{D} l_{D}+F_{I} l_{I}+F_{L} l_{L}>F_{g} l_{g}
$$

Here, we assume that the moment arms for the drag $\left(l_{D}\right)$ and inertial forces $\left(l_{I}\right)$ are the same (half the rubble height $\left.\left(l_{r h}\right) ; l_{D}=l_{I}=l_{r h} / 2 \equiv l_{H}\right)$ and that the moment arms for the lift $\left(l_{L}\right)$ and gravitational $\left(l_{g}\right)$ forces are the same (half the rubble width $\left(l_{r W}\right)$; $l_{L}=l_{g}=l_{r W} / 2 \equiv l_{W}$ ). A derivation similar to the one for the sliding threshold velocity above can be done to obtain the threshold velocities for the time-varying overturning moments (Section 4 in the Supplement).

Coefficients of drag, lift, inertia, and friction were obtained from previously published literature values. Because empirical coefficients are not well constrained for rubble movement, coefficient values were selected near the center of the range in the literature, and sensitivity analyses were conducted with a range of values. For the general case, we used a $C_{M}$ of 1.0 and tested a sensitivity range of \pm 0.5 from literature values for rubble (McDougal \& Sulisz 1990). We used a $C_{D}$ of 0.6 with a sensitivity range of \pm 0.2 as per literature values for cylinders, limpets, 
plates, and spheres (Denny 1994). We used a $C_{L}$ of 0.178 (Nott 2003) with a minimum and maximum range of 0.1 and 0.4 (Cheng \& Chiew 1998). We used a $\mu$ of 0.6 and varied by \pm 0.2 for the sensitivity analyses based on literature values from boulder transport on basalt and sand-covered limestone in laboratory studies (Voropayev et al. 2001, Noormets et al. 2004, Goto et al. 2007). Stability of a rubble clast is a function of rubble properties, including size, shape, and density (Rasser \& Riegl 2002). Rubble properties required in the above equations were obtained from statistical values obtained from morphology and density measurements of individual clasts collected from the study site (Section 5, Fig. S3, in the Supplement).

The approach above addresses individual rubble clasts. However, in a rubble field, proximity of multiple clasts likely impacts hydrodynamic forces affecting any given clast. For example, in rubble mobilization in storm conditions, clasts that become loose can knock into neighboring clasts, mobilizing rubble that would not necessarily be mobilized in isolation. Alternatively, friction can be enhanced from interlocking or by reduced area exposed to flow due to sheltering from adjacent objects. We did not incorporate friction and mechanical restraint from interlocking into forcing equations here due to the numerical complexity. We addressed a reduced area exposed to flow due to sheltering from adjacent objects by including the blocking term of Storlazzi et al. (2005) that accounts for reduction in $A_{D}$. This term has a value from $0-1$, corresponding to flow totally blocked to no blockage. We applied a value of 0.5 with recognition that a wide array of conditions is likely to exist in situ, and conducted sensitivity tests for values ranging from 0.3 to 0.9 (Fig. S4 in the Supplement).

\section{Wave model and hindcasts}

We quantified temporal variations in hydrodynamic forces at each study site over a 4 yr period using a spatially resolved ocean wave model hindcast verified with field data. Wave characteristics at the sites were computed using SWAN, a third-generation numerical wave model (Booij et al. 1999, Ris et al. 1999). SWAN solves the spectral wave action equation and accounts for wave propagation, wave generation by local winds, dissipation by bottom friction, depth-limited breaking, and water level changes. The model was forced using wind and wave parameters (1 $\mathrm{h}$ intervals) from the Caribbean Coastal Ocean Observing System (CariCOOS) buoy southeast of Ponce, Puerto Rico $\left(17.860^{\circ} \mathrm{N}, 66.52^{\circ} \mathrm{W}\right.$; Fig. 1). We employed a nested grid approach to permit adequate wave development and propagation from offshore to the complex inner shelf bottom topography. The outer model domain was $50 \mathrm{~km} \times 16 \mathrm{~km}$ with $200 \times$ $200 \mathrm{~m}$ grid cell resolution, and spanned the $25 \mathrm{~km}$ distance between the offshore buoy and the study area (Fig. 1). The nested inner grid was $16 \mathrm{~km} \times$ $10 \mathrm{~km}$ with $40 \times 40 \mathrm{~m}$ resolution and contained the study sites. Bathymetry was interpolated from the best available high-resolution NOAA hydrographic surveys (ngdc.noaa gov).

The accuracy of the wave model was assessed by comparison with field measurements from an inten-

Table 1. Description of oceanographic instrument deployment to measure wave statistics and current velocities. All instruments were deployed from 13 June to 17 July 2014. ADCP: acoustic Doppler current profiler, ADV: acoustic Doppler velocimeter

\begin{tabular}{|c|c|c|c|}
\hline Site & $\begin{array}{l}\text { Location } \\
\text { (Lat, Long) }\end{array}$ & Depth (m) & Instruments and configuration \\
\hline $\begin{array}{l}1 \text { Rubble } \\
\text { site }\end{array}$ & $\begin{array}{l}17^{\circ} 57.161^{\prime} \mathrm{N} \\
66^{\circ} 43.876^{\prime} \mathrm{W}\end{array}$ & 11.0 & $\begin{array}{l}\text { (A) } 1.2 \mathrm{MHz} \text { TRDI ADCP, } 0.25 \mathrm{~m} \text { bins } \\
1 \mathrm{~Hz} \text { sample rate with } 10 \text { mode-12 subpings, bursting for } 17 \text { min every } 0.5 \mathrm{~h} \\
\text { (B) } 6 \mathrm{MHz} \text { Nortek Vector ADV } \\
16 \mathrm{~Hz} \text { sample rate, bursting for } 17 \text { min every hour } \\
\text { (C) SeaBird SBE } 56 \text { thermistor } \\
1 \mathrm{~Hz} \text { continuous sampling }\end{array}$ \\
\hline $\begin{array}{l}2 \text { Pavement } \\
\text { site }\end{array}$ & $\begin{array}{l}17^{\circ} 57.587^{\prime} \mathrm{N} \\
66^{\circ} 46.132^{\prime} \mathrm{W}\end{array}$ & 9.6 & $\begin{array}{l}\text { (A) } 1.2 \mathrm{MHz} \text { TRDI ADCP, } 0.25 \mathrm{~m} \text { bins } \\
1 \mathrm{~Hz} \text { sample rate with } 10 \text { mode- } 12 \text { subpings, bursting for } 17 \text { min every } 0.5 \mathrm{~h} \\
\text { (B) } 6 \mathrm{MHz} \text { Nortek Vector ADV } \\
16 \mathrm{~Hz} \text { sample rate, bursting for } 17 \text { min every hour } \\
\text { (C) SeaBird SBE56 thermistor } \\
1 \mathrm{~Hz} \text { continuous sampling }\end{array}$ \\
\hline $\begin{array}{l}3 \text { Central } \\
\text { bay }\end{array}$ & $\begin{array}{l}17^{\circ} 57.701^{\prime} \mathrm{N} \\
66^{\circ} 45.416^{\prime} \mathrm{W}\end{array}$ & 10.0 & $\begin{array}{l}\text { (A) } 600 \mathrm{kHz} \text { TRDI ADCP, } 0.5 \mathrm{~m} \text { bins } \\
2 \mathrm{~Hz} \text { sample rate in Waves mode, bursting for } 17 \text { min every } 0.5 \mathrm{~h}\end{array}$ \\
\hline
\end{tabular}


sive month-long deployment (13 June to 17 July 2014) of oceanographic instruments at the study sites (Table 1, Section 3 in the Supplement). A set of 3 oceanographic moorings was deployed on the seafloor at the rubble and pavement disturbance sites and at a central location within the model domain (Fig. 2, Table 1). Each mooring contained an upwardlooking acoustic Doppler current profiler (ADCP) that burst sampled each hour measuring velocity and pressure (see Table 1 for details) to obtain bulk wave parameters of significant wave height $\left(H_{s}\right)$, peak wave period $\left(T_{p}\right)$, and peak wave direction $\left(D_{p}\right)$ following the method of Terray et al. (1990). High-resolution near-bottom velocity measurements were made using acoustic Doppler velocimeters (ADVs) deployed at the rubble and pavement disturbance sites to compute near-bottom wave-orbital velocities $\left(u_{b}\right)$. ADV velocity components were despiked following (Islam \& Zhu 2013), and $u_{b}$ values were computed using linear wave theory and integrals of the velocity spectra (Dean \& Dalrymple 1991, Wiberg \& Sherwood 2008). Numerical model predictions of $H_{s}$ were compared to in situ observations $(\mathrm{n}=890 \mathrm{~h}$ measurements over the month-long field campaign) for individual sites (Stations 1-3; Fig. 1, Table 1) and for the mean of all sites using linear regression, root mean square error (RMSE), as well as an average skill metric for the $3(N)$ sites (Willmott 1982, Hoeke et al. 2011):

skill $=\frac{1}{N} \sum^{N}\left[1-\frac{\sum^{n}\left|H_{s}^{\text {model }}-H_{s}^{\text {obs }}\right|^{2}}{\sum^{n}\left(\left|H_{s}^{\text {model }}-\bar{H}_{s}^{\text {obs }}\right|+\left|H_{s}^{\text {obs }}-\bar{H}_{s}^{\text {obs }}\right|\right)^{2}}\right]$

where skill varies between 0 and 1 , with 1 indicating perfect agreement. Model skill metrics for $u_{b}$ were computed using the same approach. Modeled $H_{s}$ and $u_{b}$ showed good agreement with observations $\left(H_{s}\right.$ model skill $=0.90, u_{b}$ model skill $=0.83$, Fig. 4, Table 2) and thus the model was deemed sufficiently accurate to be used to estimate the potential range of hydrodynamic forcing at the disturbance sites. The wave model was then run for a $4 \mathrm{yr}$ hindcast period (2010-2014) to simulate a representative range of wave conditions at the rubble and pavement disturbance sites.

To address the combined forcing of both waves and currents, we first assumed that the near-bottom flow can be described by a log-layer. We estimated the shear velocity $\left(u_{*}\right)$ from short-term field measurements of the depth-averaged velocity (e.g. Buckley et al. 2012)
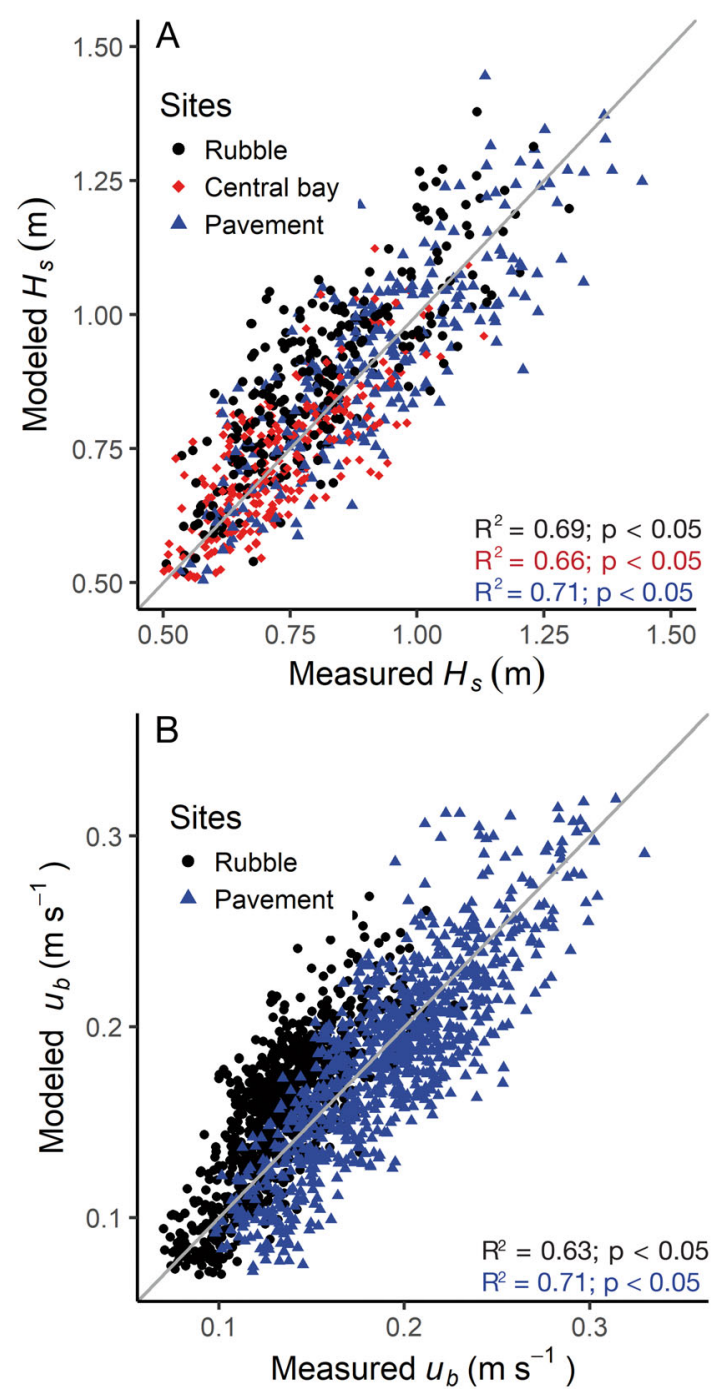

Fig. 4. Comparisons between modeled and observed (A) significant wave height $\left(H_{s}\right)$ at the 3 study sites and (B) nearbottom-orbital velocity $\left(u_{b}\right)$ at the rubble and pavement sites. Model output and observed data are for the intensive in situ oceanographic measurement periods from 13 June to 17 July 2014. Reference lines with an intercept of 0 and slope of 1 are in grey

$$
u_{*}=\frac{U}{\frac{1}{\kappa H} \int_{0}^{H} \ln \left(\frac{z+z_{0}}{z_{0}}\right) \mathrm{d} z}
$$

where $U$ is the depth-averaged velocity, $\kappa$ is the von Karman constant, $H$ is the total water column height, $z$ is the height above the sea floor, and $z_{0}$ is the roughness height. Assuming that the rubble occupies some layer above the bottom, the layer-averaged velocity $\left(u_{k}\right)$ acting on the rubble is

$$
u_{k}=\frac{u_{*}}{\kappa\left(z_{k-1}-z_{k}\right)} \int_{z_{k}}^{z_{k-1}} \ln \left(\frac{z+z_{0}}{z_{0}}\right) \mathrm{d} z
$$


Table 2. Statistical comparisons between observed and modeled significant wave heights $\left(H_{s}\right)$ and near-bottom wave-orbital velocities $\left(u_{b}\right)$ during the 13 June to 17 July 2014 oceanographic instrument deployment. RMSE: root mean square error

\begin{tabular}{|c|c|c|c|c|c|}
\hline Site & Metric & $\begin{array}{l}\text { Model } \\
\text { skill } \\
\text { (Eq. 5) }\end{array}$ & $\begin{array}{c}\text { RMSE } \\
(\mathrm{m})\end{array}$ & $\begin{array}{c}\text { Regr } \\
\text { Inter- } \\
\text { cept }\end{array}$ & $\begin{array}{l}\text { ssion } \\
\text { Slope }\end{array}$ \\
\hline 1 Rubble site & $\begin{array}{c}H_{s} \\
u_{b}\end{array}$ & $\begin{array}{l}0.88 \\
0.91\end{array}$ & $\begin{array}{l}0.12 \\
0.03\end{array}$ & $\begin{array}{l}0.14 \\
0.06\end{array}$ & $\begin{array}{l}0.91 \\
0.72\end{array}$ \\
\hline 2 Pavement site & $H_{s}$ & 0.91 & 0.11 & 0.12 & 0.86 \\
\hline 3 Central bay & $\begin{array}{c}H_{s} \\
u_{b}\end{array}$ & $\begin{array}{l}0.90 \\
0.78\end{array}$ & $\begin{array}{l}0.09 \\
0.03\end{array}$ & $\begin{array}{l}0.09 \\
0.05\end{array}$ & $\begin{array}{l}0.87 \\
0.53\end{array}$ \\
\hline Average of sites & $\begin{array}{c}H_{s} \\
u_{b}\end{array}$ & $\begin{array}{l}0.90 \\
0.84\end{array}$ & $\begin{array}{l}0.017 \\
0.03\end{array}$ & $\begin{array}{l}- \\
-\end{array}$ & $\begin{array}{l}- \\
-\end{array}$ \\
\hline
\end{tabular}

Mean depth-averaged speeds derived from shortterm ADCP measurements were 0.05 and $0.10 \mathrm{~m} \mathrm{~s}^{-1}$ for the pavement and rubble sites, respectively. Assuming a $z_{0}$ value of $0.01 \mathrm{~m}$ gives $u_{*}$ values of 0.003 and $0.007 \mathrm{~m} \mathrm{~s}^{-1}$, respectively, so from Eqs. (5) \& (6), $u_{k}$ for the pavement site was 0.02 and $0.04 \mathrm{~m} \mathrm{~s}^{-1}$ for the rubble site. These values were included as constant $U_{c}$ values in the rubble model forcing equations.

To determine the frequency of occurrence of projected hydrodynamic mobilization events, we compared 4 yr model hindcast estimates of bottom-orbital velocity at the rubble and pavement sites to timedependent threshold velocities required to mobilize rubble through sliding or overturning (Eqs. 2 \& 3) using our measured rubble properties. We identified when potential mobilization forces exceeded threshold bottom-orbital velocities at the rubble injury site and calculated time intervals between mobilization events. Only events more than $4 \mathrm{~d}$ apart were included to ensure that the interval estimates represented distinct disturbance events.

\section{RESULTS}

\section{Coral recruitment, survival, and community change}

Successful colonization of corals within the rubble site was limited by low recruitment, survival, and cover (Figs. 5, 6A,C, \& 7B). Overall change in benthic cover of scleractinian and octocorals during the study was related to the amount of rubble cover (Fig. 5). Density and survival of scleractinian coral recruits were consistently lower at the rubble site than on the reference reef or on restoration structures during

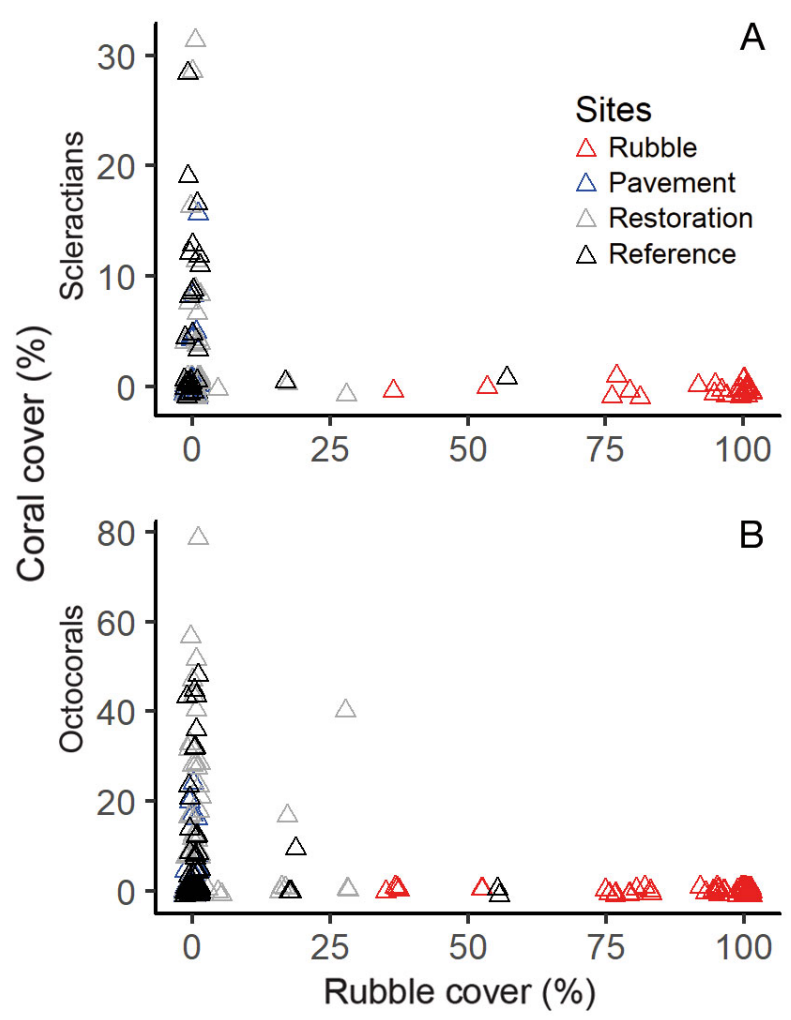

Fig. 5. Comparison of change in benthic cover of (A) scleractinian corals and (B) octocorals from 2008-2013 in relation to benthic cover of rubble substrate for rubble, reference, restoration, and reference sites

every year of the study (Figs. 5, 6A,C). As a result, coral density and species richness increased at the pavement site from 2008 to 2013, as recruits survived and grew into the larger size class (Figs. 7A,C, 8), in contrast to the rubble transects where scleractinian recruits remained in the small $(<5 \mathrm{~cm})$ size class (Fig. 7B). The change in scleractinian density during the study was also significantly higher within the pavement site than the rubble site (scleractinian rubble and pavement mean ranks were 7.8 and 13.2 , respectively; $U=0, Z=-2.6, \mathrm{p}<0.05, \mathrm{r}=-0.8$; Fig. 7 ). Scleractinian recruitment was dominated in the rubble disturbance by Siderastrea siderea, and in the pavement disturbance by $S$. siderea and Porites astreoides (Fig. 9). Scleractinian species richness averaged 9.3 within the rubble site and 10.2 at the pavement site, comparable to the 10 species observed in the restoration site, but fewer than the 22 species observed in the reference site (Fig. 9). The change in species richness from 2008 to 2013 did not differ significantly between pavement and rubble disturbances for either scleractinians or octocorals (Figs. 8 \& 9). Therefore, the observed differences in coral density and survival between the pavement 

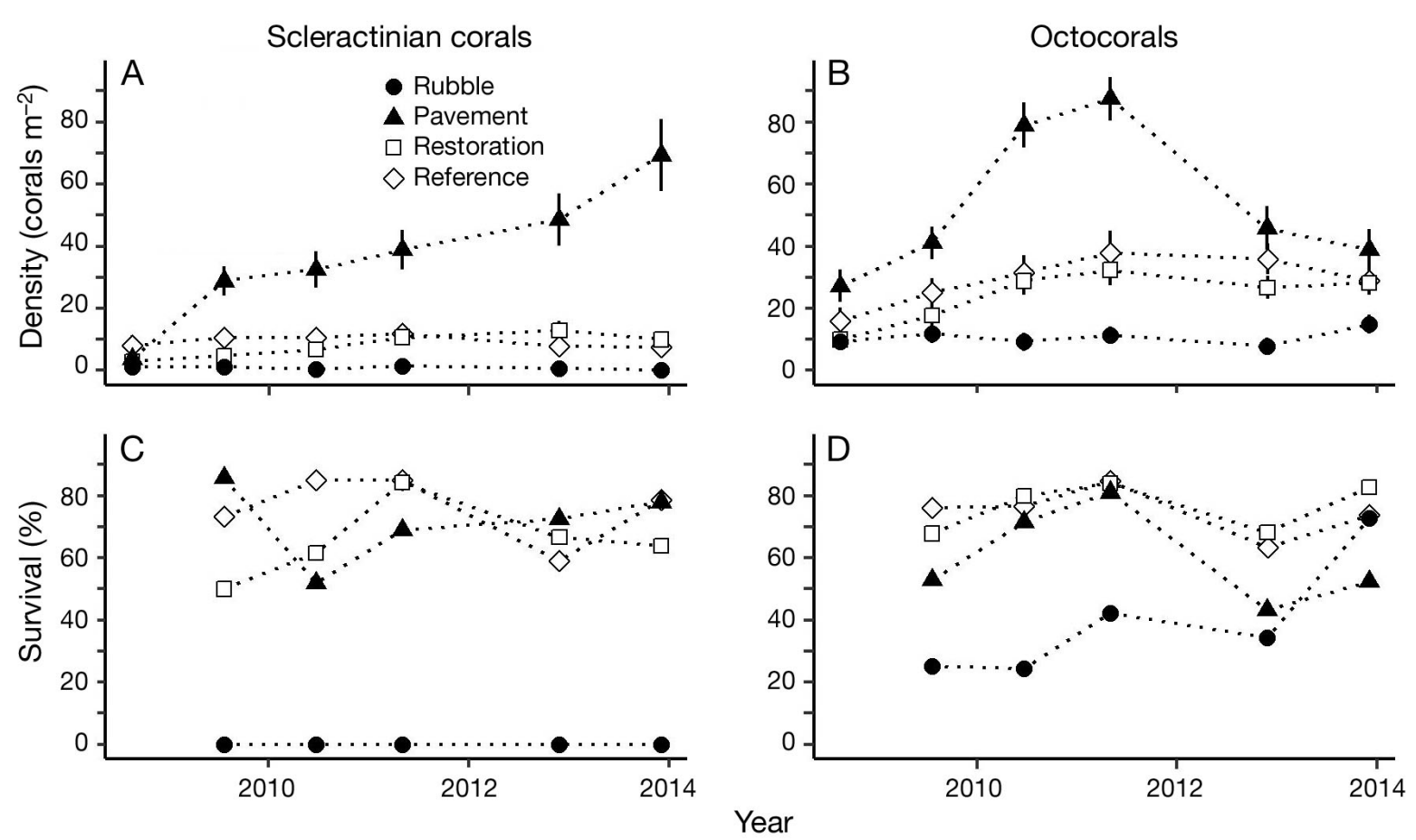

Fig. 6. Comparison of coral colonization success between rubble, pavement, restoration, and reference sites showing (A,B) density (error bars represent $\mathrm{SE}$ ) and $(\mathrm{C}, \mathrm{D})$ survival of recruits. Recruit survival represents the percentage of corals present at the previous survey
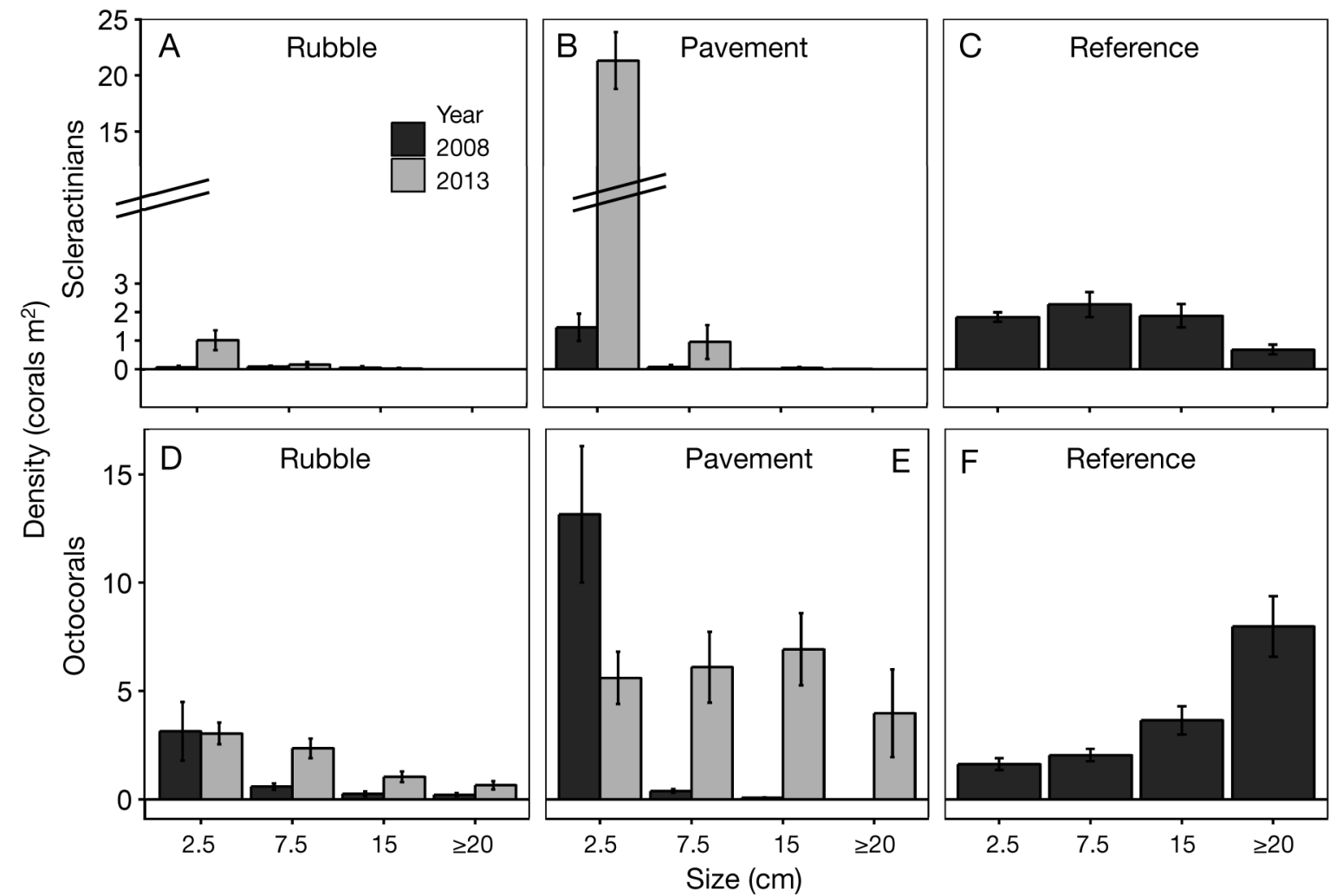

Fig. 7. Size-frequency histogram for scleractinian corals $(A-C)$ and octocorals $(D-F)$ at rubble $(A, D)$, pavement $(B, E)$, and reference $(\mathrm{C}, \mathrm{F})$ sites in 2008 (rubble, pavement, reference) and 2013 (rubble, pavement). Sizes (cm) are size-class midpoints. Error bars represent standard error of the mean 


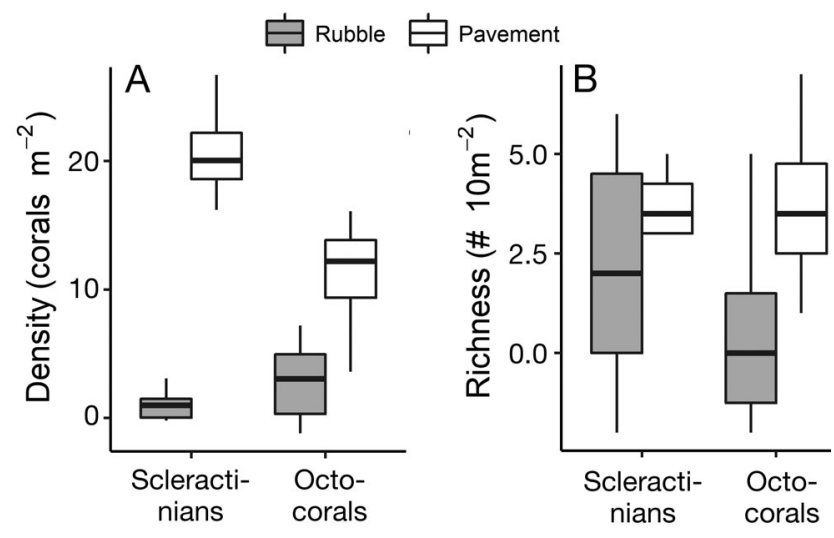

Fig. 8. Change in (A) density and (B) richness for scleractinians and octocorals from within the rubble and pavement sites. Richness shows change in number of scleractinian species and octocoral genera per $10 \mathrm{~m}^{2}$ transect

and rubble sites are likely not due to changes in community composition over time (Fig. 8), although this was not well resolved in the data due to the limited number of recruits at the rubble site. Patterns in coral density and survival were similar between the reference and restoration areas (Fig. 5), likely due to similarities in benthic cover of turf algae, macroalgae, and other organisms (Section 1, Fig. S1B, in the Supplement).
Octocoral recruit density and survival were higher than patterns seen in scleractinian corals, although still limited and variable. Density and survival of recruits were predominantly lower at the rubble site than the pavement site, reference site, or restoration structures (Figs. 6B, D, \& 7). The change in octocoral density from 2008 to 2013 was significantly higher within the pavement site than within the rubble site (rubble and pavement mean ranks were 4.9 and 9.8, respectively; $U=0$, $Z=-2.2, \mathrm{p}<0.05, \mathrm{r}=-0.6$; Fig. 7 ); this appeared due to increases in density of octocorals sized from 5 to $>20 \mathrm{~cm}$ at the pavement site (Fig. 6), as surviving octocorals grew larger. In contrast, although the density of octocorals at the rubble site was higher than that of scleractinians (Figs. $7 \& 8$ ) and some octocorals grew into larger size classes, octocoral density did not significantly increase from 2008 to 2013 (Fig. 7).

At the rubble site, analysis of benthic quadrat photographs showed that selected individual rubble clasts changed locations within permanent quadrats between field surveys, indicating repeated mobilization. Of 249 rubble clasts tracked between sampling events, only $5(2.0 \%)$ were relocated in the subsequent years' photos. These 5 consistent pieces appeared larger than the mean of the rubble size distribution, and were in approximately the same location for a single subsequent year.

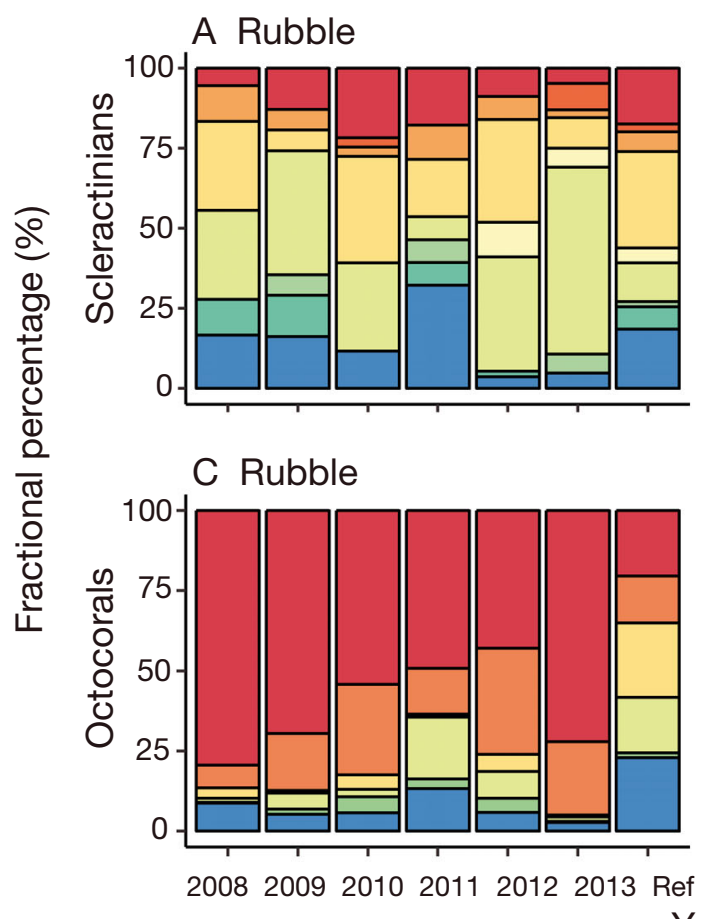

B Pavement

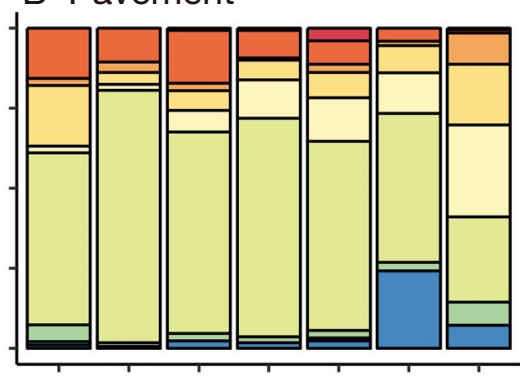

D Pavement

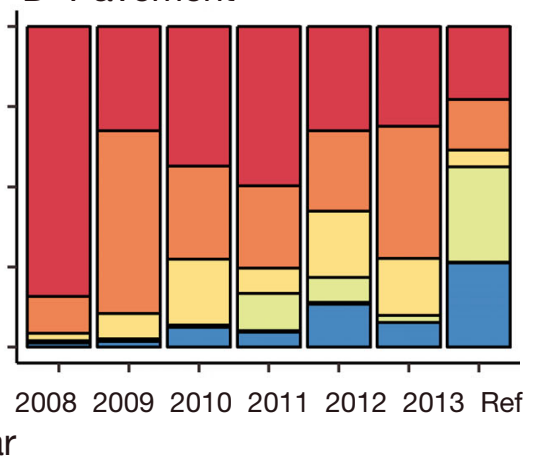

\section{Scleractinians}

Agaricia spp. Dichocoenia stokesi Montastraea cavernosa Porites astreoides Pseudodiploria strigosa Siderastrea siderea Stephanocoenia intersepta Orbicella spp. Other

\section{Octocorals}

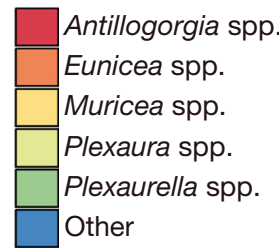

Fig. 9. Change in species composition from 2008-2013 for impacted coral communities relative to reference populations (Ref) at $(\mathrm{A}, \mathrm{C})$ pavement and $(\mathrm{B}, \mathrm{D})$ rubble sites. Scleractinian coral composition is in A and $\mathrm{B}$, and octocoral composition is in $\mathrm{C}$ and $\mathrm{D}$ 


\section{Rubble and wave energy models}

The 4 yr wave model hindcast showed that wave forcing near the substrate was similar between the rubble and pavement disturbance sites (Fig. 10). Multiple events occurred during the model hindcast period when bottom-orbital velocities exceeded thresholds required to mobilize mean-sized rubble (Figs. 11 \& 12). The mean return intervals for forcing required to slide rubble was approximately $7 \mathrm{~d}$ (maximum return interval approximately $23 \mathrm{~d}$ ), shorter than for return intervals of forces required to overturn rubble, where the mean return interval was $12 \mathrm{~d}$ (maximum $134 \mathrm{~d}_{i}$ Fig. 12A). The duration of sliding events was longer (mean $=1 \mathrm{~d}$, $\max =58 \mathrm{~d}$ ) than for overturning events (mean $=0.5 \mathrm{~d}, \max =22 \mathrm{~d}$; Fig. 12B). During multiple events each year, forcing was sufficient to slide (60-131 events $\left.\mathrm{yr}^{-1}\right)$ and overturn rubble (151-241 events $\mathrm{yr}^{-1}$ ). A number of the mobilization events are linked to the passage of tropical storms or hurricanes (Fig. 11). Forcing sufficient
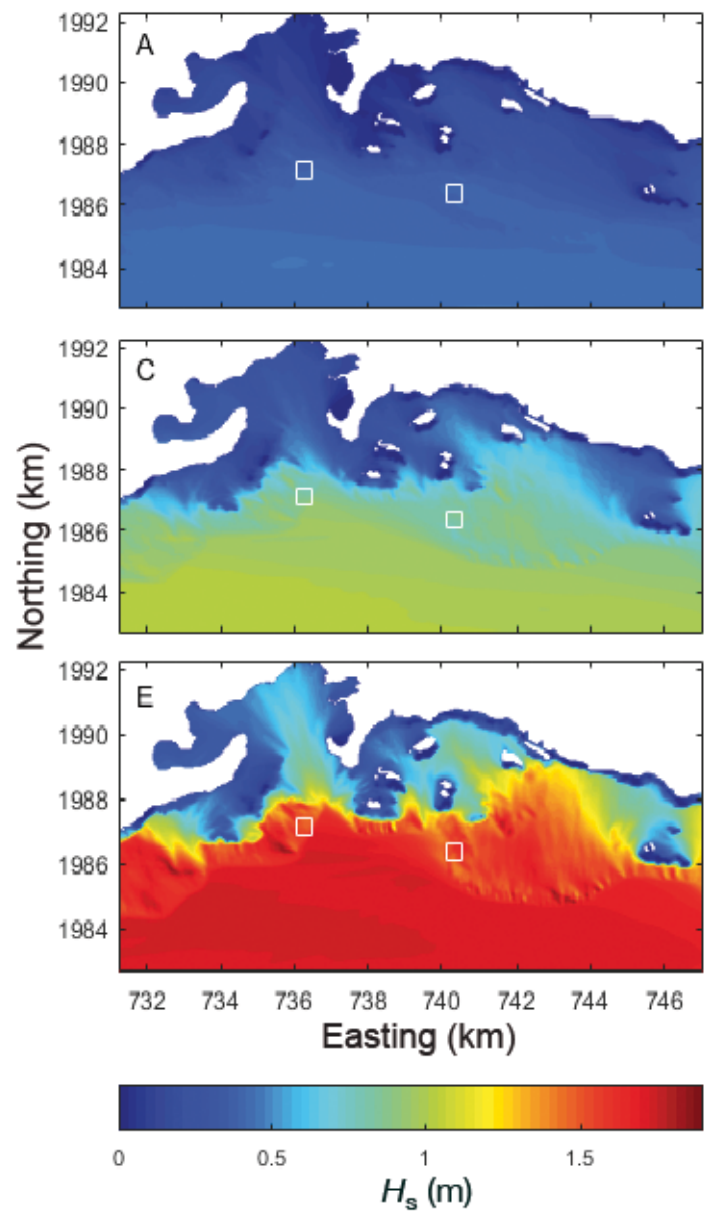

to mobilize rubble by sliding or overturning occurred in all months (Figs. 11 \& 12C), with peak occurrence in August through December during the Atlantic tropical cyclone season (Fig. 12C).

\section{DISCUSSION}

The frequency and spatial extent of multiple disturbances constrain recovery processes (Turner et al. 1993), including colonization of key species (Connell 1997). Temporal intervals between extreme events regulate coral community trajectories and return or reset communities to alternate or early successional stages (Done 1999, Hughes \& Connell 1999). Here, we show how diverging coral recovery trajectories are caused by repeated, chronic physical disturbances from wave energy. Coral colonization into 2 proximal ship grounding sites with a similar postimpact recovery time was far higher on a reef flattened to pavement than on reef area broken to rub-
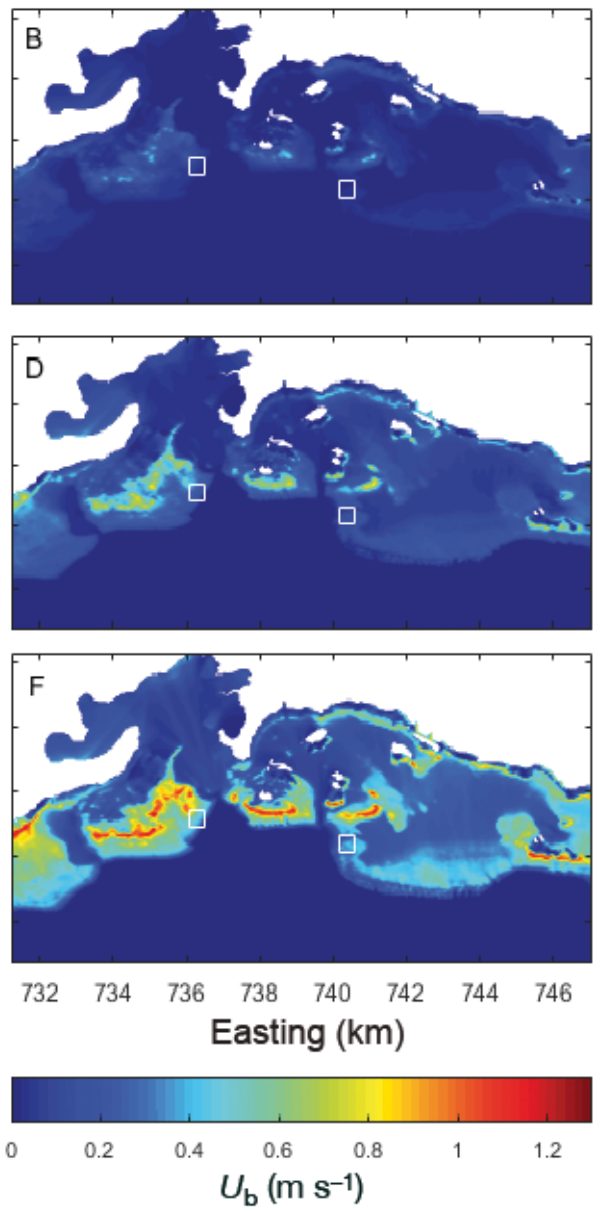

Fig. 10. Spatial distribution of $(A, C, E)$ significant wave heights and $(B, D, F)$ bottom-orbital velocities obtained from long-term wave model hindcasts: $(A, B)$ calmest $5 \%$ percentile, $(C, D)$ mean, and $(E, F)$ stormiest $95 \%$ conditions 

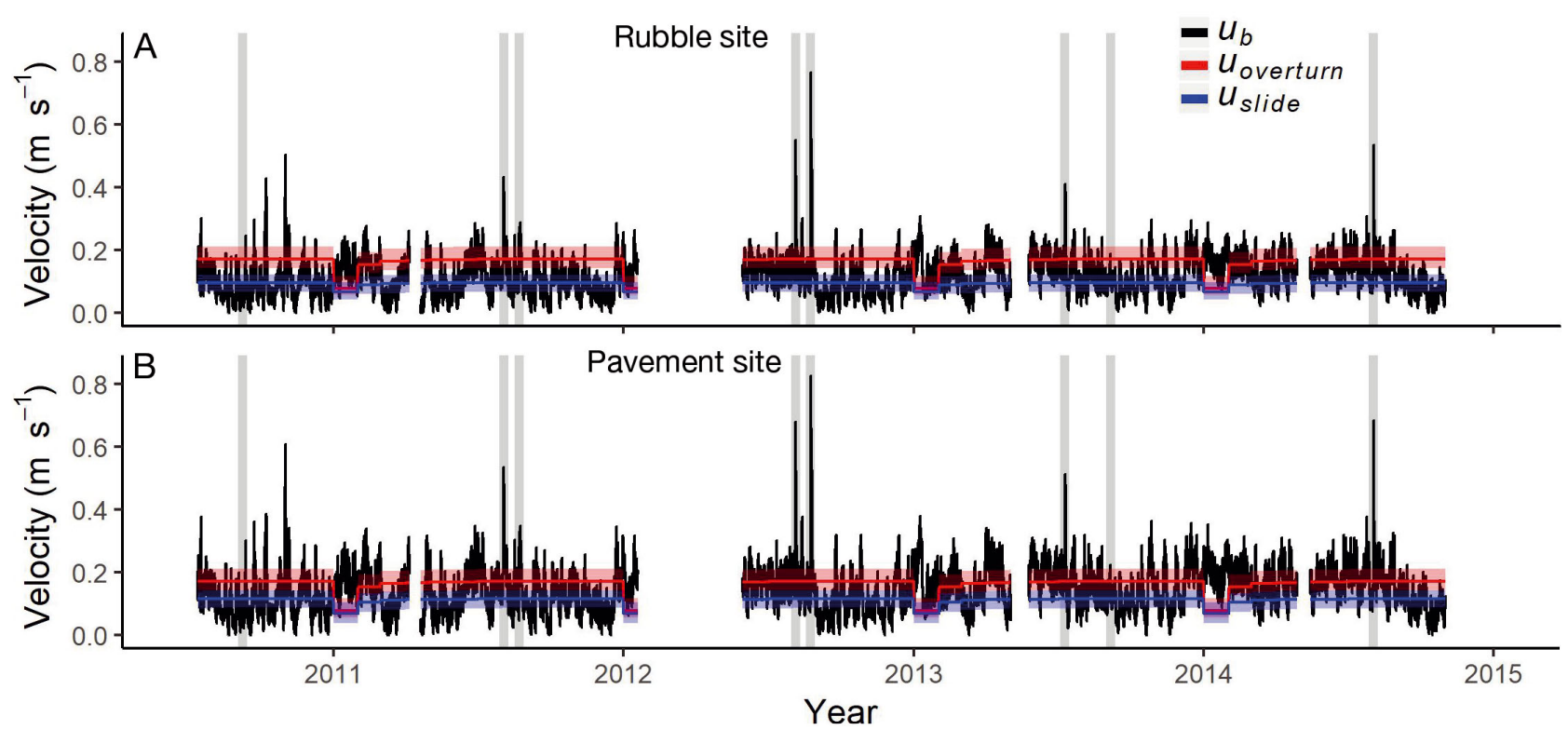

Fig. 11. Comparison between model hindcast estimates of bottom-orbital velocities $\left(u_{b}\right)$ and the critical orbital velocities required to slide $\left(u_{\text {slide }}\right)$ or overturn $\left(u_{\text {overturn }}\right)$ coral rubble at $(\mathrm{A})$ rubble and (B) pavement sites. Grey vertical lines indicate named storm events south of Puerto Rico within $100 \mathrm{~km}$. Solid red and blue lines indicate general values of coefficients used in forcing needed to overturn (red) or slide (blue) rubble. Shading indicates minimum and maximum coefficient sensitivity values for $u_{\text {slide }}$ (red) and $u_{\text {overturn }}$ (blue)
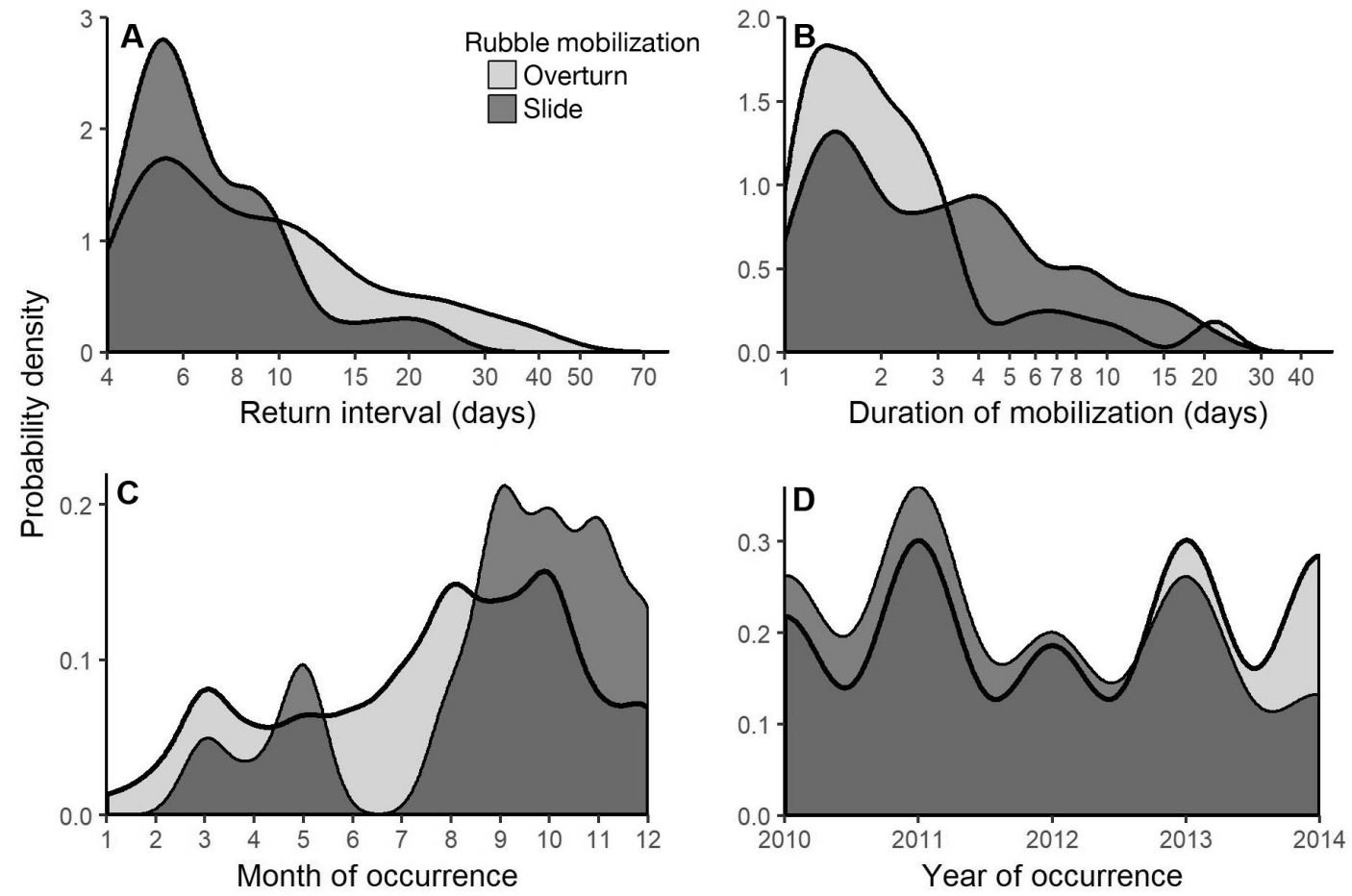

Fig. 12. (A) Return intervals (in days) between hydrodynamic forcing events that exceeded threshold levels to mobilize coral rubble through overturning (light grey) or sliding (dark grey). Return intervals for threshold conditions to overturn rubble have a longer return interval than those to slide rubble. (B) Durations of hydrodynamic forcing conditions exceeding conditions to mobilize coral rubble through overturning are shorter than those required for sliding. (C) Probability of occurrence of hydrodynamic forcing events by month. Chronic hydrodynamic forcing events of rubble occur in all months and more frequently in the hurricane season. (D) Probability of occurrence of hydrodynamic forcing events by year, showing that threshold conditions were exceeded in all study years 
ble. Recruitment density and survival on pavement substrate also initially exceeded that of the reference and restoration sites, a pattern that is likely indicative of less available benthic space in reference and restoration sites due to existing corals, octocorals, and other benthic organisms. As coral recruits at the pavement site survived and grew into larger size classes, new recruitment declined, also supporting a pattern of space availability limitations as more corals became established. In contrast, within unstable substrate, the data suggest a colonization bottleneck for corals and sustained loss of coral habitat. To contrast these diverging recovery trajectories on reefs with otherwise similar coral species composition, we further explored the potential physical mechanisms behind the observed biological patterns.

Using rubble mechanics, we showed that the hydrodynamic forcing hindcast for the study sites would be sufficient to mobilize rubble on a chronic timescale not limited to large, infrequent events such as named tropical storms. The recruitment limitations within unstable substrate observed in this study are consistent with previous studies that have shown correlations between decreased survival of small corals and substrate mobilization by water motion (Fox et al. 2003, Fox \& Caldwell 2006, Yadav et al. 2016). Our mechanistic model indicates that substrate instability lowers a threshold for subsequent hydrodynamic disturbances. Such chronic multiple disturbances limit coral colonization relative to adjacent disturbed areas with comparable hydrodynamic forcing but consolidated substrate. Without stabilization of unconsolidated rubble, the threshold for disturbance remained low and did not recover during the study. In contrast, the threshold for hydrodynamic disturbance at the pavement site was much higher, as evidenced by successful coral colonization. The fate of unstable rubble depositions is determined by frequency and intensity of subsequent hydrodynamic disturbances (Scoffin 1993), and continued mobilizations may establish a positive feedback loop in which continued rubble clast mobilizations cause additional mechanical erosion or breakage and a shift to ever smaller rubble sizes. Smaller rubble clasts subsequently mobilize at a lower level of hydrodynamic forcing, and thus become subject to more frequent and sustained disturbances.

Estimating hydrodynamic forces on submerged objects contains inherent uncertainties. Spatial variability in flow patterns (notably, at a scale smaller than the $40 \mathrm{~m}$ model grid cell resolution of this study) may influence probabilities of rubble mobilization. Small-scale flow patterns may drive hydrodynamic patchiness within a disturbance site, resulting in some areas being more likely to mobilize than others. For example, colonies along edges of undamaged reef surrounding disturbance area may have turbulent wakes (Hench \& Rosman 2013) that may influence the likelihood of rubble mobilization. Potential for substrate mobility is influenced by friction and drag forces' sensitivities to rubble exposure to the flow, rubble interlocking, or ratio of rubble to sediment. Improved modeling of rubble mobility could include rubble collisions (Imamura et al. 2008, Nandasena \& Tanaka 2013) and rubble interactions with smaller sediment size classes (Kain et al. 2012). Finally, bioturbation (e.g. sand tilefish, rays) may mobilize rubble, but is difficult to quantify on its own or in conjunction with hydrodynamic mobilization.

Alternative explanations for the comparatively lower coral recruitment into the rubble site than the pavement site include differential temperature stresses leading to mortality (e.g. via bleaching), or competition for space with existing benthic organisms such as algae. Mean near-bottom water temperature at the pavement site was slightly warmer than the rubble site, with the same variance, and skewed toward higher temperatures (Section 2, Fig. S2, in the Supplement). One might expect that greater thermal stress at the pavement site could translate to less favorable thermal conditions for coral survival; however, since coral density and survival were higher at the pavement site, it appears that thermal stress is not the dominant physical driver accounting for differences between sites. Cover of other benthic organisms also did not appear to be substantially different between the pavement and rubble sites. Both were similar in cover for benthic algae, turf, and sponges; however, the rubble site had more crustose coralline algae than the pavement site for several years (Figs. S1A \& S1B in the Supplement), a condition which would seem favorable for coral settlement (Ritson-Williams et al. 2009). Cementation and encrustation (Perry 1999) and sponge stabilization (Biggs 2013) have been reported to be biological mechanisms to stabilize substrate, and potentially provide suitable substrate for successful multi-species coral colonization (e.g. Dollar \& Tribble 1993, Hughes 1999, Perry 2005). In our study, however, only limited stabilization of unconsolidated substrate through biological mechanisms was noted, and biological stabilization was not observed to be a significant contributor to stabilize the rubble site. 
Although direct observation of rubble mobilization and coral mortality during hydrodynamic events proved elusive in this study, the findings are consistent with other work showing that large disturbances can have cascading effects that can lead to continued habitat degradation. Effects of large disturbances are well known to have longlasting impacts on coral communities (Done 1992, Connell et al. 1997, Connell 1997). Hydrodynamic energy from hurricanes is related to declines in reef structural complexity (Alvarez-Filip et al. 2009), low coral recruitment (Crabbe et al. 2008), and coral loss in the Caribbean over the last $30 \mathrm{yr}$ (Gardner et al. 2005). On Caribbean reefs, the combined effects of disturbances, adult mortality, and recruitment limitations of framework-building scleractinian coral species have contributed to community shifts to small, weedy coral species, octocorals, or algae, thereby reducing potential for future structural complexity. This limitation is likely to have impacts beyond benthic communities, as complexity provided by both corals and underlying geologic structure contributes to system-wide biodiversity (Graham \& Nash 2013), including fish communities (Graham et al. 2006), fisheries productivity (Graham 2014, Rogers et al. 2014), and mitigation of nearshore wave energy through attenuation by reefs (Ferrario et al. 2014).

After an extreme initial disturbance to the biological and structural complexity of a coral reef, projected recovery may be limited by ecological as well as hydrodynamic forcing. Our findings emphasize the importance of physical and biological limitations on juvenile coral survival and negative effects of multiple disturbances on community recovery. It is clear that without substrate stabilization, subsequent chronic hydrodynamic mobilization of unstable substrate can lead to prolonged or permanent habitat loss.

Acknowledgements. We thank Ryan Neve, Tom Moore, Greg Piniak, Brian Degan, Christine Buckel, Michael Nemeth, Katie Flynn, Sean Meehan, David Hurley, Pedro Rodriguez, and SeaVentures for their generous assistance. Constructive comments from 2 anonymous reviewers, Curt Storlazzi, Greg Piniak, Margaret Miller, Carolyn Currin, and Tom Moore improved the manuscript. This study was supported by NOAA National Centers for Coastal Ocean Science, NOAA Restoration Center, PADI Foundation, Sigma Xi Grant-In-Aid of Research, Duke University Graduate School, and the National Science Foundation (OCE1435133). The scientific results and conclusions, as well as any views or opinions expressed herein, are those of the authors and do not necessarily reflect the views of NOAA or the Department of Commerce.

\section{LITERATURE CITED}

Alvarez-Filip L, Dulvy NK, Gill JA, Cote IM, Watkinson AR (2009) Flattening of Caribbean coral reefs: region-wide declines in architectural complexity. Proc R Soc B 276: 3019-3025

* Bertness MD, Crain CM, Silliman BR, Bazterrica MC, Reyna MV, Hildago F, Farina JK (2006) The community structure of western Atlantic Patagonian rocky shores. Ecol Monogr 76:439-460

* Biggs BC (2013) Harnessing natural recovery processes to improve restoration outcomes: an experimental assessment of sponge-mediated coral reef restoration. PLOS ONE 8:e64945

* Booij N, Ris RC, Holthuijsen LH (1999) A third-generation wave model for coastal regions 1 . Model description and validation. J Geophys Res 104:7649-7666

* Buckley ML, Wei Y, Jaffe BE, Watt SG (2012) Inverse modeling of velocities and inferred cause of overwash that emplaced inland fields of boulders at Anegada, British Virgin Islands. Nat Hazards 63:133-149

Cheng N, Chiew Y (1998) Pick-up probability for sediment entrainment. J Hydraul Eng 124:232-235

Connell JH (1997) Disturbance and recovery of coral assemblages. Coral Reefs 16(Suppl 1):S101-S113

Connell JH, Hughes TP, Wallace CC (1997) A 30-year study of coral abundance, recruitment, and disturbance at several scales in space and time. Ecol Monogr 67:461-488

Crabbe MJC, Martinez E, Garcia C, Chub J, Castro L, Guy J (2008) Hurricanes and corals in Southern Belize: from science to management and policy development. In: Riegl B, Dodge RE (eds) Proc 11th Int Coral Reef Symp, Ft Lauderdale, FL, 7-11 July 2008:4, p 1173-1176

* Dayton PK (1971) Competition, disturbance, and community organization: the provision and subsequent utilization of space in a rocky intertidal community. Ecol Monogr 41: 351-389

Dayton P (1972) Toward an understanding of community resilience and the potential effects of enrichments to the benthos at McMurdo Sound, Antarctica. In: Parker BC (ed) Proceedings of the Colloquium on Conservation Problems in Antarctica. Allen Press, Lawrence, KS, p 81-95

Dean RG, Dalrymple RA (1991) Water wave mechanics for engineers and scientists. Advanced Series on Ocean Engineering Vol 2, World Scientific Publishing, Singapore

* Dennison WC, Barnes DJ (1988) Effect of water motion on coral photosynthesis and calcification. J Exp Mar Biol Ecol 115:67-77

*Denny M (1994) Extreme drag forces and the survival of wind- and water-swept organisms. J Exp Biol 194:97-115

Denny M (1995) Predicting physical disturbance: mechanistic approaches to the study of survivorship on waveswept shores. Ecol Monogr 65:371-418

* Dollar SJ, Tribble GW (1993) Recurrent storm disturbance and recovery: a long-term study of coral communities in Hawaii. Coral Reefs 12:223-233

* Done TJ (1992) Phase shifts in coral reef communities and their ecological significance. Hydrobiologia 247:121-132

* Done TJ (1999) Coral community adaptability to environmental change at the scales of regions, reefs and reef zones. Am Zool 39:66-79

光Edinger EN, Jompa J, Limmon GV, Widjatmoko W, Risk MJ (1998) Reef degradation and coral biodiversity in Indonesia: effects of land-based pollution, destructive fishing 
practices and changes over time. Mar Pollut Bull 36: $617-630$

* Ellison AM, Bank MS, Clinton BD, Colburn EA and others (2005) Loss of foundation species: consequences for the structure and dynamics of forested ecosystems. Front Ecol Environ 3:479-486

Ferrario F, Beck MW, Storlazzi CD, Micheli F, Shepard CC, Airoldi L (2014) The effectiveness of coral reefs for coastal hazard risk reduction and adaptation. Nat Commun 5:3794

Fox HE, Caldwell RL (2006) Recovery from blast fishing on coral reefs: a tale of two scales. Ecol Appl 16:1631-1635

Fox HE, Pet JS, Dahuri R, Caldwell RL (2003) Recovery in rubble fields: long-term impacts of blast fishing. Mar Pollut Bull 46:1024-1031

Gardner TA, Côté IM, Gill JA, Grant A, Watkinson AR (2005) Hurricanes and Caribbean coral reefs: impacts, recovery patterns and role in long-term decline. Ecology 86:174-184

Goto K, Chavanich SA, Imamura F, Kunthasap P and others (2007) Distribution, origin and transport process of boulders deposited by the 2004 Indian Ocean tsunami at Pakarang Cape, Thailand. Sediment Geol 202:821-837

* Graham NAJ (2014) Habitat complexity: coral structural loss leads to fisheries declines. Curr Biol 24:R359-R361

Graham NAJ, Nash KL (2013) The importance of structural complexity in coral reef ecosystems. Coral Reefs 32: 315-326

Graham NAJ, Wilson SK, Jennings S, Polunin NVC, Bijoux JP, Robinson J (2006) Dynamic fragility of oceanic coral reef ecosystems. Proc Natl Acad Sci USA 103:8425-8429

* Grant W, Madsen O (1979) Combined wave and current interaction with a rough bottom. J Geophys Res Oceans 84:1797-1808

Harmelin-Vivien ML (1994) The effects of storms and cyclones on coral reefs: a review. J Coast Res 12SI: 211-231

Hench JL, Rosman JH (2013) Observations of spatial flow patterns at the coral colony scale on a shallow reef flat. J Geophys Res Oceans 118:1142-1156

Hoegh-Guldberg O, Mumby PJ, Hooten AJ, Steneck RS and others (2007) Coral reefs under rapid climate change and ocean acidification. Science 318:1737-1742

Hoeke R, Storlazzi C, Ridd P (2011) Hydrodynamics of a bathymetrically complex fringing coral reef embayment: wave climate, in situ observations, and wave prediction. J Geophys Res 116:C04018

Hughes TP (1999) Off-reef transport of coral fragments at Lizard Island, Australia. Mar Geol 157:1-6

Hughes TP, Connell JH (1999) Multiple stressors on coral reefs: a long-term perspective. Limnol Oceanogr 44: 932-940

Hughes TP, Baird AH, Bellwood DR, Card M and others (2003) Climate change, human impacts, and the resilience of coral reefs. Science 301:929-933

Imamura F, Goto K, Ohkubo S (2008) A numerical model for the transport of a boulder by tsunami. J Geophys Res Oceans 113:C01008

Islam M, Zhu D (2013) Kernel density-based algorithm for despiking ADV data. J Hydraul Eng 139:785-793

Jaap WC (2000) Coral reef restoration. Ecol Eng 15:345-364

Kain CL, Gomez C, Moghaddam AE (2012) Comment on 'Reassessment of hydrodynamic equations: Minimum flow velocity to initiate boulder transport by high energy events (storms, tsunamis), by N.A.K. Nandasena, R. Paris and N. Tanaka [Marine Geology 281, 70-84]. Mar Geol 319-322:75-76

Lenihan HS, Hench JL, Holbrook SJ, Schmitt RJ, Potoski M (2015) Hydrodynamics influence coral performance through simultaneous direct and indirect effects. Ecology 96:1540-1549

* Lirman D, Miller MW (2003) Modeling and monitoring tools to assess recovery status and convergence rates between restored and undisturbed coral reef habitats. Restor Ecol 11:448-456

Madin JS (2005) Mechanical limitations of reef corals during hydrodynamic disturbances. Coral Reefs 24:630-635

Kass T, Genin A, Shavit U, Grinstein M, Tchernov D (2010) Flow enhances photosynthesis in marine benthic autotrophs by increasing the efflux of oxygen from the organism to the water. Proc Natl Acad Sci USA 107:2527-2531

McDougal WG, Sulisz W (1990) Wave interaction with rubble bases. J Coast Res 7SI:139-147

*Nandasena NAK, Tanaka N (2013) Boulder transport by high energy: numerical model-fitting experimental observations. Ocean Eng 57:163-179

* Nandasena NAK, Paris R, Tanaka N (2011) Reassessment of hydrodynamic equations: minimum flow velocity to initiate boulder transport by high energy events (storms, tsunamis). Mar Geol 281:70-84

Noormets R, Crook KAW, Felton EA (2004) Sedimentology of rocky shorelines: 3.: Hydrodynamics of megaclast emplacement and transport on a shore platform, Oahu, Hawaii. Sediment Geol 172:41-65

Nott J (2003) Waves, coastal boulder deposits and the importance of the pre-transport setting. Earth Planet Sci Lett 210:269-276

* Pearson RG (1981) Recovery and recolonization of coral reefs. Mar Ecol Prog Ser 4:105-122

Perry CT (1999) Reef framework preservation in four contrasting modern reef environments, Discovery Bay, Jamaica. J Coast Res 15:796-812

*Perry CT (2005) Structure and development of detrital reef deposits in turbid nearshore environments, Inhaca Island, Mozambique. Mar Geol 214:143-161

Piniak G (2002) Effects of symbiotic status, flow speed, and prey type on prey capture by the facultatively symbiotic temperate coral Oculina arbuscula. Mar Biol 141:449-455

Rasser M, Riegl B (2002) Holocene coral reef rubble and its binding agents. Coral Reefs 21:57-72

Riegl B (2001) Degradation of reef structure, coral and fish communities in the Red Sea by ship groundings and dynamite fisheries. Bull Mar Sci 69:595-611

Ris RC, Holthuijsen LH, Booij N (1999) A third-generation wave model for coastal regions: 2. Verification. J Geophys Res Oceans 104:7667-7681

Ritson-Williams R, Arnold SN, Fogarty ND, Steneck RS, Vermeij MJA, Paul VJ (2009) New perspectives on ecological mechanisms affecting coral recruitment on reefs. Smithson Contrib Mar Sci 38:437-457

* Rogers A, Blanchard JL, Mumby PJ (2014) Vulnerability of coral reef fisheries to a loss of structural complexity. Curr Biol 24:1000-1005

Scheffers SR, Haviser J, Browne T, Scheffers A (2009) Tsunamis, hurricanes, the demise of coral reefs and shifts in prehistoric human populations in the Caribbean. Quat Int 195:69-87

Scoffin TP (1993) The geological effects of hurricanes on coral reefs and the interpretation of storm deposits. Coral Reefs 12:203-221 
Sebens KP, Johnson AS (1991) Effects of water movement on prey capture and distribution of reef corals. Hydrobiologia 226:91-101

Sheppard CRC, Spalding M, Bradshaw C, Wilson S (2002) Erosion vs. recovery of coral reefs after 1998 El Niño: Chagos Reefs, Indian Ocean. Ambio 31:40-48

Sheppard C, Dixon DJ, Gourlay M, Sheppard A, Payet R (2005) Coral mortality increases wave energy reaching shores protected by reef flats: examples from the Seychelles. Estuar Coast Shelf Sci 64:223-234

Steneck R, Paris C, Arnold S, Ablan-Lagman M and others (2009) Thinking and managing outside the box: coalescing connectivity networks to build region-wide resilience in coral reef ecosystems. Coral Reefs 28: 367-378

Stoddart DR (1969) Post-hurricane changes on the British Honduras reefs and cays. Atoll Res Bull 131:1-25

Storlazzi CD, Brown EK, Field ME, Rodgers K, Jokiel PL (2005) A model for wave control on coral breakage and species distribution in the Hawaiian Islands. Coral Reefs 24:43-55

Terray EA, Krogstad HE, Cabrera P, Gordon RL, Lohrmann A (1990) Measuring wave direction using upwardlooking Doppler sonar. In: Proceedings of the IEEE

Editorial responsibility: Emily Carrington,

Friday Harbor, Washington, USA
Fourth Working Conference on Current Measurement. IEEE Press, Clinton, MD, p 252-257

* Turner MG, Romme WH, Gardner RH, O'Neill RV, Kratz TK (1993) A revised concept of landscape equilibrium: disturbance and stability on scaled landscapes. Landsc Ecol $8: 213-227$

* Voropayev SI, Cense AW, McEachern GB, Boyer DL, Fernando HJS (2001) Dynamics of cobbles in the shoaling region of a surf zone. Ocean Eng 28:763-788

*Wakeford M, Done TJ, Johnson CR (2008) Decadal trends in a coral community and evidence of changed disturbance regime. Coral Reefs 27:1-13

*Wiberg PL, Sherwood CR (2008) Calculating wave-generated bottom orbital velocities from surface-wave parameters. Comput Geosci 34:1243-1262

Willmott CJ (1982) Some comments on the evaluation of model performance. Bull Am Meteorol Soc 63:1309-1313

Woodley JD, Chornesky EA, Clifford PA, Jackson JBC and others (1981) Hurricane Allen's impact on Jamaican coral reefs. Science 214:749-755

* Yadav S, Rathod P, Alcoverro T, Arthur R (2016) 'Choice' and destiny: the substrate composition and mechanical stability of settlement structures can mediate coral recruit fate in post-bleached reefs. Coral Reefs 35:211-222

Submitted: November 29, 2016; Accepted: July 26, 2018

Proofs received from author(s): October 9, 2018 